\title{
Rebalancing the Teaching-Research Nexus for Quality Teaching and Learning Environment at the Tertiary Level in Nigeria
}

\author{
Obi, Osorochi Patricia (Ph.D.), \\ Department of Science Education, College of Agricultural and Science Education, Michael Okpara University \\ of Agriculture, P M B 7267, Umudike, Umuahia, Abia State, Nigeria
}

\begin{abstract}
This is a quantitative study stressing on the need to rebalance research and teaching nexus. Research and teaching are intertwined characteristics of a university. There should be stronger connections between research activities and teaching roles. Effective teaching-research links are not automatic and have to be consciously constructed and implemented. The changing world to be faced by today's students and tomorrows graduates will demand unprecedented skills of intellectual flexibility, analytical ability and sense of enquiry fostered by research-oriented approach to teaching. Universities need to be reformulated to help students and society deal with the ever changing complex society. The teaching research nexus is central to university education. This paper examined the link between teaching and research in relation to quality teaching and learning environment at the tertiary level in Nigeria. It highlighted the inherent benefits of a balanced teaching and research, identified the reasons for apparent disconnect, the basic assumptions fueling this disconnect and streamlined possible ways of strengthening the link and integrating research into teaching in tertiary institutions in Nigeria. This paper is intended to expand and improve existing knowledge and inform policies in the area of research and teaching nexus.
\end{abstract}

Keywords: Learning environment, Nigeria, quality teaching, teaching-research nexus, tertiary education,

\section{Introduction}

Nations are trying to transform their economies into knowledge economies requiring that research be shared with society. Through teaching, higher education plays an important role in disseminating and promoting the use of research. Social and cultural changes accompany economic changes which call for citizens who are able to think critically and possess essential skills and virtues [1]. To help all students to learn in and for this changing environment, academics as university teachers need a better understanding of teaching, research and learning issues as well as to advance their pedagogic competencies. Many current methods such as widespread lecturing relegate students to passivity, tend to focus narrowly on subject knowledge, and thus are inadequate [1]. Research on learning has demonstrated that students understand better, remember ideas more effectively, and think more incisively when they feel personally responsible for getting meaning out of what they are learning instead of waiting for the teacher to shovel it in [2]. Unless and until university teachers develop themselves professionally, keeping pace with the modern world, they cannot be expected to contribute meaningfully to the education of the youth in the $21^{\text {st }}$ century [3]. Higher education is becoming a major driver of economic competitiveness in an increasingly knowledge-driven global economy. The imperative for countries to improve employment skills, calls for quality teaching in a conducive learning environment within educational institutions. Quality teaching must be thought of dynamically, in the light of contextual shifts in the higher education environment.

Tertiary education is post secondary education including teaching and research at public and private universities, technical, lifelong learning and adult education institutes, community colleges and their equivalents, and specialized institutions for professional and vocational training, distance learning, and executive education. The tertiary learning experience that we build with our students needs to be sustainable and help prepare our students to perform in the $21^{\text {st }}$ century workplace and to contribute to society. The objectives of tertiary education reflect national economic and social objectives. Tertiary education produces professional and technical expertise to meet the expanding needs of their economies. They develop 'world class' research and training and equip students with skills for personal and community development and are sources of values, attitudes and formation of social skills. It is hard to achieve these objectives if research and teaching agenda are at cross purposes. The quality of tertiary education should be measured by the extent to which it fulfills these objectives. The skills, creativity and research developed through higher education are major factors in the success of any nation in creating jobs on which their prosperity rests [4]. 


\section{Rebalancing the Teaching-Research Nexus}

Most tertiary institutions have consistently placed research at the very core of their activities. They have hired high-level lecturers and offered a wide range of scholarship activities and research opportunities, thereby minimizing the teaching process. International ranking of institutions are mostly based on impact factor generated through research activities [5]. Evaluation methods tend to overemphasize research, and to use research performance as a yardstick of an institution's value [6]. In Nigerian universities, the major criterion for academic staff promotion is the number and quality of research papers in reputable journals. This has given rise to the common dictum "publish or perish." Most academic staff desirous not to perish spend substantial part of their time working on their research interests. This creates a disconnect between teaching and research activities at the tertiary level.

The disconnect between some of our teaching and research strengths is not in the interest of students, staff or the institution as a whole. The best teaching occurs when active researchers use their expertise in teaching, while research ideas and approaches are stimulated and sharpened through interactions with students. Being research active and sharing those research findings in class takes the learning experience to the next higher level.

Research-intensive institutions have difficulty raising the profile of teaching compared to research. They argue that research is typically encapsulated in laboratories for the purpose of knowledge creation and transfer, which ultimately benefit the reputation of the institution. The purpose of the teaching delivered is scarcely an issue and remains on the margins of academics' thoughts. New pressures are challenging these universities, forcing them to take a closer look at the concept of quality teaching and to contemplate institutional support to step up the quality of the faculty and curricula.

\subsection{Reasons for the disconnect between teaching and research}

Reasons have been adduced for the disconnect between teaching and research at the tertiary level. Time constraint is at the base of this disconnect. Hattie and Marsh (2004) identify the disproportionate commitment to either one of these dimensions which will have a negative impact on the performance in the other area. They also assert that the traits are different for both. Research activity is generally individualistic, solitary and private whereas teaching is an interactive activity. Additionally, institutions despite giving lip-service to the importance of teaching still prioritize research [7]. The basic criterion for professional growth is publication. You publish or perish even if you are the best teacher. Career advancement is primarily linked to research output. National policies for promoting research appear to damage the relationship. Systemic barriers therefore make it difficult for teaching and research to be positively correlated [8]. Research and teaching are core to the requirements of tertiary education and the demands of higher performance on both fronts are increasing. It has long become an assumption within the university that research activity is the most common manifestation of scholarship. As a result, research endeavours have tended to be considered by some to be of higher status and more valuable than teaching. Efforts should be focused on ways of strengthening this nexus which is the bedrock of true scholarship.

Our understanding of true scholarship is expanded by Yapa [9] who states that it is a scholarly activity generating new knowledge through academic reflection on issues of community engagement, integrating research, teaching and service for community upliftment. Public scholarship is a useful way of combining all the domains of intellectual activity into a distinctive whole [10]. Learning is viewed as a process of discovering how one might contribute to society using scholarly knowledge and processes.

\subsection{Basic Assumptions on the Disconnect Between Teaching and Research}

There are some assumptions holding sway in the academic world which tend to widen the gap between teaching and research. These have been articulated by Spiller [11] as follows:

* Active researchers are at the 'cutting edge' of their discipline. It is assumed that researchers are per se up with the latest developments in their field, and that this must therefore positively affect their teaching.

* It is a given for academics. This is an incontrovertible aspect of university education.

* The same attributes characterize successful researchers and successful teachers- high level of commitment, focus, organization of materials, analysis and communication.

* The enthusiasm generated for the teacher by active engagement in research will rub off on the students. The underlying premise is that the teacher will communicate the passion and energy generated by active involvement in research to students who will in turn be excited by the subject and the possibility offered by research.

* Academics can offer their students first-hand knowledge from research and students will respond to the authenticity and credibility of a teacher who is actively engaged in research. 
The assumptions that active research inevitably benefits students have been challenged [11]. The relationship between research and teaching has been increasingly contested by educators [7]. A study [12] found zero relationship between teaching and research. No empirical support was found between undergraduate teaching and research in the university [13]. Many existing data collection, evaluation and reward systems retard rather than promote a positive relationship between teaching and research [14]. Seeking ways of synergizing these two facets to maximize the benefits for student learning has been suggested.

\section{Ways of Strengthening the Nexus between Teaching and Research}

There is need to synergize research and teaching to maximize the opportunities that their complementary relationship can offer for both teachers and learners. Academics need to deliberately and explicitly consider ways of making research count in what happens for the learners, and to develop this understanding through sound and reflective teaching. In a knowledge society, all students certainly all graduates have to be researchers. They should not only be engaged in the production of knowledge, they should also be educated to cope with the risks and uncertainties generated by the advance in science and technology [15].

The true conception of a modern university is one that maintains a symbiotic relationship between teaching and research [16]. The relationship needs active management and explicit support since the pressures to split the two apart are powerful. The following ways have been suggested to foster better alignment between research and teaching at the individual, departmental, institutional and professional levels [17]:

$\checkmark$ Academics creating learning environments in which the development of research-minded disposition is a deliberate part of planning and implementation of teaching and learning activities.

$\checkmark \quad$ Working from the paradigm of your students as co-inquirers.

$\checkmark \quad$ Introducing your research explicitly into your teaching.

$\checkmark$ Inviting students to participate in your research activities.

$\checkmark$ Designing inquiry-based learning and assessment activities.

$\checkmark \quad$ Inviting your students to engage with the uncertain and unresolved.

$\checkmark$ Searching your discipline journals to show how teachers have helped students to develop research attitudes.

$\checkmark$ Publishing their findings.

$\checkmark$ Achieving a better balance between individual and departmental reward systems.

$\checkmark \quad$ Strategic policy alignment.

$\checkmark \quad$ Transparency in promotion and appointment exercises.

$\checkmark$ Extending institutional learning from the outcomes of strategically funded projects.

$\checkmark \quad$ The development of better and, where possible, common metrics for teaching and research.

$\checkmark$ Professionally mandated curriculum and pedagogical reviews.

\subsection{Integrating Research into Teaching}

A study [18] by Zubrick and his associates proffer ways of integrating research into teaching to foster the teaching -research nexus. Some of them are:

- Teaching students how research within their discipline leads to knowledge creation.

- Introducing students to current research in their discipline.

- Teaching students methods of carrying out research in their discipline.

- Motivating students to learn through knowledge of and direct involvement in research.

- Letting students carry out research, are assessed and feedback provided.

- Showing students how research is organized, research grants sought for and funded.

\section{Quality Teaching and Learning Environment}

There is no firm consensus within the field as to what exactly constitutes high-quality teaching or a quality teacher. Quality teachers are distinguished by their mastery of content, command of a broad set of pedagogic skills, communication/interpersonal skills and a positive effect on student learning. Quality teachers are life-long learners in their subject areas, teach with commitment, and are reflective upon their teaching practice. They transfer knowledge of their subject matter and the learning process through good communication, diagnostic skills, understanding of different learning styles and cultural influences, knowledge about lifespan development, and the ability to marshal a broad array of techniques to meet student needs. They set high expectations and support students in achieving them. They establish an environment conducive to learning, and leverage available resources outside as well as inside the classroom [19].

The quality of teaching and learning is a vital part of the quality of higher education. There is need to broaden criteria of academic quality in order to include not only the quality of research but also of teaching provision. This means paying more attention to the pedagogic competencies and skills of those engaged in teaching. The quality of an education system cannot exceed the quality of its teachers. It has become increasingly clear that the quality of teacher education is among the most important factors shaping the learning 
and growth of students [20, 21]. Quality teaching is not divorced from conducive learning environment. Teaching-learning environment describe the whole set of teaching, learning support, assessment and administrative arrangements, as well as the facilities and resources provided within a degree course [22]. Emphasis is on those aspects expected to influence most directly the quality of student learning. Student learning is enhanced by the effective planning and organization of learning environments, including the use of available human resources and the provision of physical and virtual resources. High quality university teaching requires the development of the scientific mind.

The imperative for countries to improve employment skills calls for quality teaching within our tertiary institutions. Education and the challenges of preparing quality teachers are important priorities in many countries. The success of any nation in education depends on the quality of its teachers. Competent and effective teachers help build a strong educational system and a vibrant and virile economy [23]. Quality teaching may be considered as a distinctive feature contributing to the overall quality of the institution, along with scientific reputation and the quality of learning environment. Emphasis on quality education requires the teaching force to be competent in curriculum delivery. Transference of learning requires knowledge, skills and attitudes from technical know-how to the creative art of teaching. The guiding premise is that teaching is a dynamic and a lively profession. In today's knowledge economy, teachers are lifelong learners with specific professional needs.

To ensure the provision of efficient teachers especially at the tertiary level, who possess the relevant knowledge, skills and attitudes to teach effectively, teachers should also be properly supported and adequately remunerated to ensure high levels of motivation $[24,25]$. A robust policy to encourage quality teaching is likely to strengthen learning outcomes. Central to any quality teaching and learning environment is a culture of improvement through quality enhancement processes. For quality enhancement, there needs to be an institutional mandate that such processes are important. Teaching is a core business with the purpose of advancing, preserving and promoting the ideals, knowledge and values of higher education [26].

The main hope for realizing a genuinely student-centered undergraduate education lies in reengineering the teaching-research nexus [27]. Disciplinary research can inform and enhance the teaching and learning environment, benefiting students during their degree studies and when they move into the world of employment and for lifelong learning. It will deepen students' understanding of the knowledge bases of disciplines and professions. It will also build students' higher-order intellectual capabilities and develop their capacity to conduct research and engage in independent learning.

\section{Suggestions}

As noted above, the pressures to separate teaching from research at the tertiary level are so powerful. This is due in part to the reward system that is inextricably linked to publication both for the individual and for the institutions. Global rankings of universities are purely based on their research activities as seen in high impact journals. Funding of research activities more than teaching activities has further weakened the string binding teaching with research. In the light of the above, this paper suggests the following:

$>$ A review of the assessment and promotion of all academic staff to reflect a proper balance between teaching and research activities.

$>$ A review of the curriculum at the tertiary level to integrate research into every topic in every academic discipline and to include research output as part of student session assessment not just at the end of their final year.

$>$ National Universities Commission to ensure quality teaching at the tertiary level by organizing in-service programme on tertiary teacher education for all tertiary teachers and ensuring that all incoming ones get grounded in tertiary pedagogies.

$>$ Governments and education stakeholders should ensure adequate funding of teaching and research activities including dissemination of research findings and setting up research incubation centres.

\section{Conclusion}

The best teaching takes place when active researchers use their expertise to inform teaching, while research ideas and approaches are stimulated and sharpened through interactions with students. Teaching and research at the tertiary level are inseparable. They complement each other. Society can be served better when teaching, research and dissemination of research findings are synergistically tied in the activities of both staff and students in tertiary institutions in Nigeria. 


\section{References}

[1] G. Pleschova, E. Simon, K. M. Quinlan, J. Murphy, T. Roxa, and M. Szabo, Professionalization of academics as teachers in higher education. Science Position paper. European Science Foundation, 2012.

[2] M. Healey, Developing the scholarship of teaching in higher education: a discipline-based approach, Higher Education Research \& Development 19(2), 2000, 167-187.

[3] J. Hossain, Professional development of higher education teachers: can ODL contribute? Turkish Online Journal of Distance Education-TOJDE, 11 (1), 2010, paper 8.

[4] S. Rowland, The enquiring university (Maidenhead England: 2006, Open University Press).

[5] E. Hazellkorn, The impact of league tables and ranking systems on higher education decision making, Higher Education Management and Policy, 19(2) 2008.

[6] F. Henard, Learning Our Lesson: review of quality teaching in higher education. International Management in Higher Education. 2003, OECD Papers.

[7] N. Haigh, The scholarship of teaching and learning: a practical introduction and critique. Ako. Aotearoa, The National Centre for Tertiary Teaching Excellence, 2010, www.akoaotearoa.acnz.

[8] A. Zahra, Tensions associated with the scholarship of teaching and learning. In TDU, 2011, University of Waikato.

[9] L. Yapa, Public scholarship in postmodern university. In R. A. Eberly \& J. Cohen. (Eds.) Laboratory for public scholarship and democracy New Directions for Teaching, 2006

[10] J. A. Ramaley, Embracing civic responsibility, AAA/E Bulletin, 52, 2000, 9-13.

[11] D. Spiller, Tertiary teaching: exploring our beliefs. Teaching Development. Wahanga, Wakapakari, Ako, $2012,1-41$.

[12] J. Hattie and H. W. Marsh, One journey to unravel the relationship between research and teaching. Presentation at the international colloquium on research and teaching: closing the divide? Winchester, March 2004, 18-19, www.solvent.ac.uk/externalUp/315/hattie marsh_paper.doc.

[13] A. Jenkins, A guide to research evidence on teaching research relations. The Higher Education Academy. 2004. http://www.heacademy.ac.uk/assets/york/document.

[14] J. A. Ramaley, Research and Teaching: closing the Divide? Policy Implications at the National Level in the United States. National Science $\quad$ Foundation. $2004 \quad$ Marwell Conference. http://portallive.solent.ac.uk/university/rtconference/2004/resources/ramaley_paper.pdf

[15] P. Scott, A lot to learn: we are all researchers now, Education Guardian, 8 January, 13.2002, Retrieved from: http://education.guardian.co.uk/egweekly/story/0,,628918,00.html

[16] P. L. Lee, Teaching research nexus at the University of South Australia. Discussion Draft, 2007.

[17] A. Jenkins, R. Preen and R. Lindsey, Reshaping teaching in higher education. (Great Britain, Kogan, 2003, P. 51).

[18] A. Zubrick, I. Reid and P. Rossiter, Strengthening the nexus between teaching and research. Canberra: 2001, Department of Education, Training and Youth Affairs.

[19] The Center for High Impact Philanthropy. (2010). High impact philanthropy to improve teaching quality in the U.S. Philadelphia, PA: 2010, Retrieved from http://www.impact.upenn.edu/our_work/documents/UPenn_CHIP_TQProjectBlueprint_Mar10pdf

[20] L. Darling-Hammond, and J. Bransford, Preparing teachers for a changing world: what teachers should learn and be able to do, Jossey Bass, 2006, San Francisco.

[21] A. L. Goodwin, Defining teacher quality: is consensus possible? In M. Cochran-Smith, S. Feiman-Nemser, D. J. McIntyre, and K. E. Demers (Eds.) Handbook of Research on Teacher Education: Enduring Questions in Changing Contexts, (Routledge, New York, 2008, 399-403.)

[22] S. Higgins, E. Hall, K. Wall, P. Woolner, and C. McCaughey, The Impact of School Environments: A literature review, The Centre for Learning and Teaching, School of Education, Communication and Language Science, 2005, University of Newcastle. Retrieved from <http://www.cfbt.com/PDF/91085.pdf>.

[23] S. Chong, and P. Ho, Quality teaching and learning: a quality assurance framework for initial teacher preparation programmes, Int. J. Management in Education, 3(3/4), 2009, 302-314.

[24] B. M. Pozarnik, Improving the quality of teaching and learning in higher education through supporting professional development of teaching staff. Napredak 150 (3-4), 2009, 341-359.

[25] A. M. Hightower, R. C. Delgado, K. Sellers, and C. B. Swanson, Improving student learning by supporting quality teaching: key issues, effective strategies. Bethesda, Editorial Projects in Education Inc., 2011, 1-56.

[26] M. Healey and A. Jenkins, Developing undergraduate research and inquiry. Research Report to the Higher Education Academy, York, UK, 2009, Higher Education Academy. www.heacademy.ac.uk/resources/detail/resources/publications/Healey Jenkins Developing Undergraduate

[27] A. Jenkins, and M. Healey, Institutional strategies to link teaching and research. York: 2005, The Higher Education Academy. Available at: www.heacademy.ac.uk/resources.asp?process=full_record\&section=generic\&id=585. 